\title{
Genotoxic and cytotoxic potential of methacrylate-based orthodontic adhesives
}

\author{
Andreas Taubmann $^{1} \cdot$ Ines Willershausen ${ }^{2}$ (1) $\cdot$ Christian Walter $^{3} \cdot$ Sarah Al-Maawi $^{4} \cdot$ Bernd Kaina $^{5} \cdot$ Lina Gölz $^{2}$
}

Received: 7 July 2019 / Accepted: 3 September 2020 / Published online: 24 September 2020

(C) The Author(s) 2020

\begin{abstract}
Objectives The biocompatibility of methacrylate-based adhesives is a topic that is intensively discussed in dentistry. Since only limited evidence concerning the cyto- and genotoxicity of orthodontic adhesives is available, the aim of this study was to measure the genotoxic potential of seven orthodontic methacrylate-based adhesives.

Materials and methods The XTT assay was utilized to determine the cytotoxicity of Assure Plus, Assure Bonding Resin, ExciTE F, OptiBond Solo Plus, Scotchbond Universal Adhesive, Transbond MIP, and Transbond XT after an incubation period of $24 \mathrm{~h}$ on human gingival fibroblasts. We also performed the $\gamma \mathrm{H} 2 \mathrm{AX}$ assay to explore the genotoxic potential of the adhesives within cytotoxic dose ranges after an incubation period of $6 \mathrm{~h}$.

Results The XTT assay showed a concentration-dependent reduction in cell viability. The decrease in cellular viability was in the same dose range most significant for Assure Plus, rendering it the adhesive material with the highest cytotoxicity. Employing the $\gamma \mathrm{H} 2 \mathrm{AX}$ assay, a concentration-dependent increase in $\mathrm{H} 2 \mathrm{AX}$ phosphorylation was detected, indicating induction of DNA damage.

Conclusions For most products, a linear correlation between the material concentration and $\gamma \mathrm{H} 2 \mathrm{AX}$ foci was observed. The most severe effect on $\gamma \mathrm{H} 2 \mathrm{AX}$ focus induction was found for Transbond MIP, which was the only adhesive in the test group containing the co-initiator diphenyliodonium hexafluorophosphate (DPIHP).

Clinical relevance The data indicate that orthodontic adhesives, notably Transbond MIP, bear a genotoxic potential. Since the study was performed with in vitro cultivated cells, a direct translation of the findings to in vivo exposure conditions should be considered with great diligence.
\end{abstract}

Keywords $\gamma \mathrm{H} 2 \mathrm{AX}$ assay $\cdot$ Orthodontic adhesives $\cdot$ Methacrylates $\cdot$ DPIHP $\cdot$ Biocompatibility

Andreas Taubmann and Ines Willershausen contributed equally to this work.

Ines Willershausen

ineswill@me.com

1 Department of Operative Dentistry, Johannes Gutenberg University Hospital Mainz, Mainz, Germany

2 Department of Orthodontics and Orofacial Orthopedics, Friedrich-Alexander University Erlangen-Nürnberg, Erlangen, Germany

3 MEDI+ Mainz, Private Practice, Mainz, Germany

4 Frankfurt Orofacial Regenerative Medicine (FORM) Lab, Department for Oral, Cranio-Maxillofacial and Facial Plastic Surgery, Medical Center of the Goethe University Frankfurt, Frankfurt/Main, Germany

5 Institute of Toxicology, University Medical Center Mainz, Mainz, Germany

\section{Introduction}

The inception of adhesive techniques to orthodontics in the late 1960s has resulted in a focus on resin materials $[1,2]$. Adhesive materials are currently well-established in orthodontic practice and are routinely used when applying fixed buccal/ lingual bracket systems, attachments or retainers [3-5]. When dental materials are applied within the oral cavity, their biological safety is crucial to the clinical success of the respective treatment [6]. During the course of orthodontic bonding in particular, when the supernatant adhesive is homogenized by means of air pressure, monomers will come into close contact with the marginal gingiva, the vestibular mucosa or even become diluted in the aqueous oral cavity. It has been previously questioned whether the application of adhesives prior to bracket placement, escape of adhesive materials from the bracket base, incomplete removal from the tooth surface, and insufficient light curing pose a direct hazard to the oral 
environment [7]. As a consequence, the capacity of methacrylate-based dentin adhesives to exert adverse local or even systemic effects is of increased interest $[8,9]$. With regard to the toxicity of different orthodontic adhesives, chemically cured liquid-paste materials have been confirmed to be more cytotoxic than light-cured materials [10]. Previous findings suggest the use of single cured systems since they appear to be superior to dual-cured systems in terms of a higher degree of conversion, less leaching and therefore lower cytotoxicity [11].

Bonding agents have further been investigated with regard to their effect on different cell lines. They have been reported to disrupt the cellular redox state of pulp cells in monolayer cultures and induce apoptosis and cell-cycle arrest of MDPC23 , undifferentiated pulp cells (OD-21), and macrophages [12-15]. With regard to the type of monomer, BisGMA has been shown to be highly toxic in close proximity to gingival fibroblasts, and TEGDMA induces apoptosis in cultured hGFs in a dose- and time-dependent manner [11, 16, 17]. HEMA was further shown to provoke accumulation of cells in the S-phase caused by DNA damage, and both HEMA and BisGMA induce oxidative DNA damage [18, 19].

The literature describes multiple methacrylate DNAdamaging mechanisms. A direct DNA effect, in which methacrylate carbon-carbon double bonds interact with the nucleophilic centers of the DNA, has been discussed as a mechanism behind [20]. Another possible mechanism is the induction of reactive oxygen species (ROS), which leads to oxidation products of DNA bases and DNA strand breaks. DNA breakage occurs during the process of DNA repair, notably through base excision repair (BER) removing oxidized DNA lesions such as 8-oxo-guanine. Overlapping single-strand breaks that arise from oxidative damage and overlapping BER patches can further cause DNA double-strand breaks (DSB) due to replication fork collapse [21]. In vitro experiments showed that antioxidants, such as ascorbic acid and $\mathrm{N}$ acetylcysteine, reduce the level of DSBs following treatment with methacrylates, suggesting that DNA damage relies on the induction of ROS and the formation of epoxides rather than on the direct interaction of methacrylates (e.g., BisGMA, HEMA, TEGDMA, and UDMA) with the DNA [16, 20, 22, 23]. Due to increased knowledge regarding DNA repair and damage responses, $\gamma \mathrm{H} 2 \mathrm{AX}$-dependent approaches have evolved as a reliable tool for the detection of DNA damage in dental material sciences [22, 24]. Nikolova et al. pointed out that prior to testing materials with regard to their genotoxicity, their respective cytotoxicity should be assessed in order to establish the proper dose range [25]. Based on recent evidence $[16,23,26]$, we decided to evaluate the genotoxic potential of seven commercially available light-cured, single-bottle orthodontic adhesives (Assure Plus, Assure Bonding Resin, ExciTE F, OptiBond Solo Plus, Scotchbond Universal Adhesive, Transbond MIP, and Transbond XT). Although polymerized dentin adhesives are known to exhibit a lower cytotoxicity than their unpolymerized counterparts, we consciously chose to test the adhesives in their uncured form to adhere to the in vivo conditions within the oral cavity.

In addition to the XTT and Live/Dead assay to determine the cytotoxicity, we employed the $\gamma \mathrm{H} 2 \mathrm{AX}$ foci assay for detecting possible genotoxic effects induced by the materials. Since $\gamma \mathrm{H} 2 \mathrm{AX}$ can be considered a reliable bio-indicator for pretoxic DNA damage such as DSB and blocked replication forks [25], we investigated seven different orthodontic adhesive materials with respect to their ability to provoke $\gamma \mathrm{H} 2 \mathrm{AX}$ formation in human gingival cells.

\section{Materials and methods}

\section{Cell culture}

Human gingival fibroblasts (hGFs), derived from fragments of marginal gingiva harvested during the osteotomy of third molars, were isolated and cultured. Isolated hGFs were characterized by their spindle-shaped morphology and by expression of typical marker genes like fibronectin, vimentin, and Tuj-1 [27, 28]. Healthy volunteers (two males and two females, aged 15-18 years) were informed prior to treatment and agreed on donating explant material for experimental purposes. The study was conducted in accordance with the second Helsinki Declaration and was approved by the Ethics Committee of the University of Mainz. Isolated gingival tissue, free of epithelium and alveolar bone, was incubated in Dulbecco's Modified Eagle's Medium (DMEM) (Sigma, Taufkirchen, Germany) supplemented with $10 \%$ fetal calf serum (Sigma, Taufkirchen, Germany), $1 \%$ penicillin/streptomycin, and $1 \%$ fungizone (Sigma, Taufkirchen, Germany) at $37{ }^{\circ} \mathrm{C}$ and $5 \% \mathrm{CO}_{2}$. After 3 weeks of incubation, primary colonies had formed. The cells were reseeded and cultivated in DMEM supplemented with $10 \%$ fetal calf serum (Sigma, Taufkirchen, Germany) and $1 \%$ penicillin/streptomycin at $37^{\circ} \mathrm{C}$ and $5 \% \mathrm{CO}_{2}$. For passaging and seeding of the cells, trypsin/EDTA solution was used (Sigma, Taufkirchen, Germany). Subsequent experiments were performed with cells from passage numbers 4-7.

\section{XTT proliferation assay}

The cytotoxic potential of seven methacrylate-based adhesives was determined using the Cell Proliferation Kit II (XTT) (Roche, Mannheim, Germany). The working principle is to detect the conversion of tetrazolium salts into photometrical detectable formazan dye by the reducing potential of the outer surface of intact cell membranes, and therefore the presence of a viable cell population [29,30]. The day before the experiment, hGFs were seeded into 96-well plates 
(Greiner, Frickenhausen, Germany) (10.000 cells per well). On the day of the experiment, liquid adhesives (Assure Plus, Pelz \& Partner; Assure Bonding Resin, Pelz \& Partner; ExciTE F, Ivoclar Vivadent; OptiBond Solo Plus, Kerr; Scotchbond Universal Adhesive, 3M Espe; Transbond MIP, 3M Unitek; Transbond XT, 3 M Unitek) were diluted 1:10 $(\mathrm{v} / \mathrm{v})$ in DMEM, avoiding direct exposure to light. The resulting predilution was applied to adherently growing hGFs in the 96-well plates (Greiner, Frickenhausen, Germany) at dilution factors of 1:3, 1:10, 1:30, 1:100, and $1: 300(\mathrm{v} / \mathrm{v})$ and incubated for $20 \mathrm{~h}$. Subsequently, the wells were washed once with phosphate-buffered saline (PBS) (Sigma, Taufkirchen, Germany), and fresh cell culture medium was added. The activated XTT reagent, as specified by the manufacturer, was applied to the wells and incubated at $37^{\circ} \mathrm{C}$ and $5 \% \mathrm{CO}_{2}$ for $4 \mathrm{~h}$. Specific photometric absorbance of the formazan dye was measured at $450 \mathrm{~nm}$ and $670 \mathrm{~nm}$ as a reference wavelength, using the Synergy HT microplate reader (Biotek, Winooski, USA). As a control, cells were treated with cell culture medium. For the specimen Assure Sealant, Excite F, Optibond Solo, Scotchbond Universal, Transbond MIP, and Transbond XT, six experiments and therefore six individual values have been combined $(n=6)$. For the specimen Assure Plus, nine experiments and therefore nine individual values have been combined $(n=9)$. The treated specimens were normalized to the untreated control cells. To estimate the half maximum effect (EC50) of the tested material in terms of cytotoxicity/cell viability, a four-parameter logistic model was computed [31].

\section{Live/Dead assay}

To validate the outcome of the EC50 estimation, e.g., determination of a specimen dose with a half maximum effect in terms of cell viability, the Live/Dead cell viability assay (Molecular Probes, Carlsbad, CA) was performed. For visual identification of viable cells with intact cell membranes, the green fluorescent dye calcein was utilized. In contrast, cells without a competent cell membrane, which were considered damaged or dead, provided an insufficient diffusion barrier for the ethidium homodimer. Therefore, this fluorescent dye can intercalate into the cell nucleus and emit a red fluorescent signal. For the Live/Dead assay, hGFs were seeded in 24well plates ( 40.000 cells per well) on the day before the experiment. On the day of the experiment, the previously determined effective concentration (EC50), a higher $(\times 3)$ and a lower concentration $(\times 1 / 3)$ of the specimen, was applied to the cells. After incubation for $20 \mathrm{~h}$, the cells were washed one time with PBS (Sigma, Taufkirchen, Germany) and stained as specified by the manufacturer. Stained cells were viewed using an inverted microscope Axiovert 40 CFL (Carl Zeiss, Jena, Germany) at wavelengths of $450 / 520 \mathrm{~nm}$ at a $\times 100$ magnification, and images were captured using an Axio
Cam MRC and Axiovision software (Carl Zeiss, Jena, Germany).

\section{YH2AX assay}

Human gingival fibroblasts were seeded (75.000 per well) on coverslips (Knittel, Braunschweig, Germany) in 6-well plates (Greiner, Frickenhausen, Germany) 2 days before the experiment. On the day of the experiment, stock solutions of the adhesives were prepared by mixing the adhesive liquids at a $1: 10$ ratio with DMEM $(10 \%$ FCS $)(v / v)$. The medium in the culture vessels was removed, and dilutions of the stock solution at a ratio of 1:20, 1:60, and 1:180 were added to the cultured cells. As a positive control, $1 \mathrm{mM}, 0.33 \mathrm{mM}$, or $0.1 \mathrm{mM}$ methyl methanesulfonate (MMS) (Sigma, Taufkirchen, Germany) were added directly to the cell culture medium. After $1 \mathrm{~h}$, the coverslips were washed once with PBS and incubated for another $6 \mathrm{~h}$ in fresh cell culture medium. As a control, fresh culture medium was added to the cells. After a 6-h treatment/recovery time, the cells were fixed using a 15min treatment with 4\% paraformaldehyde (Merck, Darmstadt, Germany) in PBS (Sigma, Taufkirchen, Germany).

Cells were washed once with PBS and permeabilized with ice-cold methanol (Merck, Darmstadt) at $-20{ }^{\circ} \mathrm{C}$ for $10 \mathrm{~min}$. The specimens were rehydrated by three washing steps with PBS for $5 \mathrm{~min}$ and incubated with a blocking reagent (3\% BSA, $0.25 \%$ Triton X-100 in PBS) for $1 \mathrm{~h}$. Primary antibody (mouse anti-phospho-H2AX Ser 139, \#05-636, Millipore) was diluted 1:1000 in PBS 0.25\% Triton X-100 and incubated overnight at $4{ }^{\circ} \mathrm{C}$. After three washing steps with PBS for 5 min, the secondary antibody diluted to 1:500 in PBS 0.25\% Triton X-100 was incubated for $1 \mathrm{~h}$ at room temperature. After three washing steps with PBS for $5 \mathrm{~min}$, the cells were incubated with $0.4 \mu \mathrm{g} / \mathrm{ml}$ DAPI (Roche, Mannheim) in $\mathrm{ddH}_{2} \mathrm{O}$ for another $5 \mathrm{~min}$. Single cover glasses were mounted with $2-\mu l$ antifade medium (Vectashield) and nail polish on microscope slides. Microscopic images of the cell nuclei were acquired using the Axio Imager M1 (Carl Zeiss, Jena, Germany) and Metafer 4 software (Metasystems, Altlussheim, Germany). Fluorescence signals of DAPI and Alexa Fluor 488 were detected in 5 planes with a $0.5-\mu \mathrm{m}$ focus plane distance at a magnification of $\times 1000$. Using Metafer 4 software, the single focus planes were computed into z-projections for automated focus analysis. To score the $\gamma \mathrm{H} 2 \mathrm{AX}$ focus levels per cell, we used ImageJ (Fiji) as an automated focus counting tool, a method previously described by Nikolova et al. [25]. Three individual experiments were conducted, analyzing 80 cells per experiment and applied concentration, therefore obtaining two hundred forty individual values $(n=240)$. The individual values were summarized as means and the standard deviations were calculated. 


\section{Statistical analysis}

For analysis of the XTT assay, the quantitative study data were examined by analysis of variance (ANOVA) with correction by Tukey post hoc assessment to compare the groups using SPSS Statistics software 23.0 (SPSS Inc., Chicago, USA). Analysis of data derived from the $\mathrm{yH} 2 \mathrm{AX}$ assay was performed by group comparisons using the Kruskal-Wallis test with SPSS Statistics software 23.0 (SPSS Inc., Chicago, USA). Differences were considered significant if the $p$ values were less than $0.05(p<0.05)$.

\section{Results}

\section{Effect of methacrylate-based adhesives on cell viability}

With an increasing concentration of the adhesive, all the investigated specimens showed a steady decrease in cell viability after $24 \mathrm{~h}$. At the highest and lowest adhesive concentrations, the cell viability reached a plateau. For Assure Bonding Resin, ExciTE F, OptiBond Solo Plus, Scotchbond Universal Adhesive, Transbond MIP, and Transbond XT, the most pronounced decrease in cell viability was observed as dilutions of 1:10 and 1:30 were added to the cells. For Assure Plus Bonding Resin, a major reduction in cell viability was observed with a dilution range from 1:100 to 1:30. None of the tested products showed a significant amount of formazan formation at a dilution of lower than 1:10, indicating complete cell death at this high concentration level. To differentiate the adhesives based on their cytotoxicity, their relative toxicity was determined. Therefore, data from the XTT assay were employed to compute a sigmoidal dose-effect curve with the assistance of a four-point logistic model curve fitting algorithm [31] (Fig. 1). As an indicator of the validity of the fitted curve in relation to the previous measurements, the root mean square error (RMSE) was calculated. The RMSE was $<0.02$ for all the fitted curves.

The half maximum effect of a substance in terms of cell viability is referred to as the concentration at which formazan formation is half maximum compared with the controls (EC50). Considering the fitted curve, the EC50 value corresponded to the point immediately between the upper and lower plateau and the point with the highest slope, respectively. The EC50 was lowest for the adhesive Assure Sealant Universal Bonding Resin (Dilution factor 17.9), and hence this product was considered to be the least toxic, immediately followed by Transbond XT, Scotchbond Universal Adhesive, ExciTE F, Optibond Solo Plus, and Transbond MIP (Table 2). Notably, concentrations of Assure Plus 4.37-fold lower than those of Assure Sealant were equally effective.
To validate the estimated EC50 values, microscopic investigation of the cell monolayer utilizing the Live/Dead assay was performed (Fig. 2). Dilutions of the adhesives were used that corresponded to the calculated EC50. In addition, a lower $(\times 1 / 3)$ and a higher $(\times 3)$ concentration were utilized to represent the upper and lower plateau of the relevant sigmoidal curve. For all tested products, the EC50 $\times 1 / 3$ concentration did not alter the cell viability and resembled a healthy proliferating cell culture without any ethidium homodimer staining after $24 \mathrm{~h}$ of exposure.

A good correlation between the applied conditions of cell monolayer culture and microscopic evaluation, regarding the distribution of dead/dying cells when applying the EC50, was found for Assure Plus, Assure Sealant, ExciTE F, Transbond MIP, and Transbond XT. A portion of cells showed red nuclear staining, representing the dead fraction of the cell population, but also showed dim green cytoplasmic staining. The other part of the population exhibited dim green staining, without the red nuclear staining, most likely representing cells with residual enzymatic activity and intact cellular membrane, therefore counted as alive. Significantly, both types demonstrated an altered, condensed cell morphology compared with the specimen with EC50 $\times 1 / 3$ treatment.

The morphology of the cells treated with Optibond Solo and Scotchbond Universal at EC50 dilution differed from the other respective samples. Despite displaying viable and dead cells, the cell morphology was less homogeneous, partly rounded up and stretched, with some exhibiting bright green cytoplasmic staining.

Cells that had been treated with the EC50 $\times 3$ dilution of the corresponding adhesive were exclusively stained red and counted as dead. Only the ExciTE F specimen exhibited dim cytoplasmic in addition to nuclear staining. In the case of the EC50 $\times 3$ dilution of Transbond XT, all cell nuclei were stained with the ethidium homodimer. Notably, large round blobs with dim green fluoresce remained in the specimen. Likely as a consequence of the fluorescent signals in the blue channel (not depicted), the blobs were considered to be residual adhesive coating the cell culture vessel, which was also visible in the EC50 sample.

\section{Elucidating the genotoxic potential of the dental adhesives via the $\mathrm{yH} 2 \mathrm{AX}$ assay}

Taking into account that the previously tested adhesives showed cytotoxic effects depending on a rather broad range of adhesive dilutions (1:17.9 to 1:78.2), we attempted to compare the potential genotoxic effects of the substances. Of note, the clinician would likely apply considerably similar amounts of material during treatment, irrespective of the utilized product. Therefore, we attempted to test for potential genotoxic effects with similar dilutions of the different products as they might be present in the aqueous environment of the oral 
Table 1 Composition of the adhesive materials

\begin{tabular}{|c|c|c|c|c|}
\hline Product & Supplier & Composition & $\%$ & CAS \\
\hline Assure Plus All Surface & \multirow[t]{4}{*}{ Pelz \& Partner } & Bisphenol A glycidyl dimethacrylate & $20-50$ & $1565-94-2$ \\
\hline Bonding Resin & & Ethanol & $30-50$ & $64-17-5$ \\
\hline \multirow[t]{2}{*}{ LOT 163091} & & 10-Methacryloyldodeylphosphate & $5-25$ & $85590-00-7$ \\
\hline & & 2-Hydroxyethyl methacrylate & $5-25$ & $868-77-9$ \\
\hline Assure Sealant Universal & \multirow[t]{4}{*}{ Pelz \& Partner } & Acetone & $50-75$ & $67-64-1$ \\
\hline Bonding Resin & & 2-Hydroxyethyl methacrylate & $10-30$ & $868-77-9$ \\
\hline \multirow[t]{2}{*}{ LOT 156787} & & Bisphenol A glycidyl dimethacrylate & $10-30$ & $1565-94-2$ \\
\hline & & Proprietary monomer & $10-30$ & \\
\hline ExciTE $\mathrm{F}$ dental adhesive & Ivoclar Vivadent & Bisphenol A glycidyl dimethacrylate & $25-50$ & $1565-94-2$ \\
\hline \multirow[t]{5}{*}{ LOT V08590 } & & Ethanol & $10<25$ & $64-17-5$ \\
\hline & & 2-Hydroxyethyl methacrylate & $10<25$ & $868-77-9$ \\
\hline & & Propenoic Acid & $10<25$ & $223681-84-3$ \\
\hline & & Diurethane dimethacrylate & $3-<10$ & $72869-86-4$ \\
\hline & & Potassium fluoride & $0.3<1$ & $7789-23-3$ \\
\hline OptiBond Solo Plus & Kerr & Ethanol & $10-30$ & $64-17-5$ \\
\hline \multirow[t]{3}{*}{ LOT 5365766} & & 2-Hydroxyethyl methacrylate & $10-30$ & $868-77-9$ \\
\hline & & 2-Hydroxy-1,3-propanediyl bismethacrylate & $1-5$ & $1830-78-0$ \\
\hline & & Alkali fluorosilicates $(\mathrm{Na})$ & $0.1-1$ & $16,893-85-9$ \\
\hline Scotchbond Universal & 3 M Espe & 2-Hydroxyethyl methacrylate & $15-25$ & $868-77-9$ \\
\hline Adhesive & & Bisphenol A glycidyl dimethacrylate & $15-25$ & $1565-94-2$ \\
\hline \multirow[t]{11}{*}{ LOT 631026} & & Ethanol & $10-15$ & $64-17-5$ \\
\hline & & Ingredients without classification & $10-15$ & \\
\hline & & Silane-treated silica & $5-15$ & $122334-95-6$ \\
\hline & & Decamethylendimethacrylate & $5-15$ & $6701-13-9$ \\
\hline & & 2-Proprionic acid, 2-methyl-reaction products with & & \\
\hline & & 1,10-Decanediol and phosphorus oxide (P2O5) & $1-10$ & $1207736-18-2$ \\
\hline & & Copolymer of acrylic and itaconic acid & $1-5$ & $25,948-33-8$ \\
\hline & & Campherquinone & $<2$ & $10373-78-1$ \\
\hline & & N,N-Dimethylbenzocaine & $<2$ & $10287-53-3$ \\
\hline & & (Dimethylamino) ethylmethacrylate & $<2$ & $2867-47-2$ \\
\hline & & Butanone & $<0.5$ & $78-93-3$ \\
\hline Transbond MIP & 3 M Unitek & Ethanol & $30-40$ & $64-17-5$ \\
\hline \multirow[t]{9}{*}{ LOT N775853 } & & Bisphenol A glycidyl dimethacrylate & $15-25$ & $1565-94-2$ \\
\hline & & 2-Hydroxyethyl methacrylate & $10-20$ & $868-77-9$ \\
\hline & & 2-Hydroxy-1,3-propanediyl bismethacrylate & $5-15$ & $1830-78-0$ \\
\hline & & Copolymer of acrylic and itaconic acid & $5-15$ & $25,948-33-8$ \\
\hline & & Diurethane dimethacrylate & $1-10$ & $72,869-86-4$ \\
\hline & & Water & $1-10$ & $7732-18-5$ \\
\hline & & Diphenyliodonium hexafluorophosphate & $<1$ & $58109-40-3$ \\
\hline & & N,N-Dimethylbenzocaine & $<0.5$ & $10287-53-3$ \\
\hline & & Triphenylantimony & $<0.5$ & $603-36-1$ \\
\hline Transbond XT & 3 M Unitek & Bisphenol A glycidyl dimethacrylate & $45-55$ & $1565-94-2$ \\
\hline Light Cure Adhesive Primer & & Triethylene Glycol Dimethacrylate & $45-55$ & $109-16-0$ \\
\hline \multirow[t]{4}{*}{ LOT N763457 } & & Triphenylantimony & $<1$ & $603-36-1$ \\
\hline & & 4-(Dimethylamino)-benzene ethanol & $<0.5$ & $50438-75-0$ \\
\hline & & Campherquinone & $<0.3$ & $10373-78-1$ \\
\hline & & Hydroquinone & $<0.03$ & $123-31-9$ \\
\hline
\end{tabular}

Names of substances specified in variable manners by the manufacturers but with corresponding CAS numbers have been adjusted 


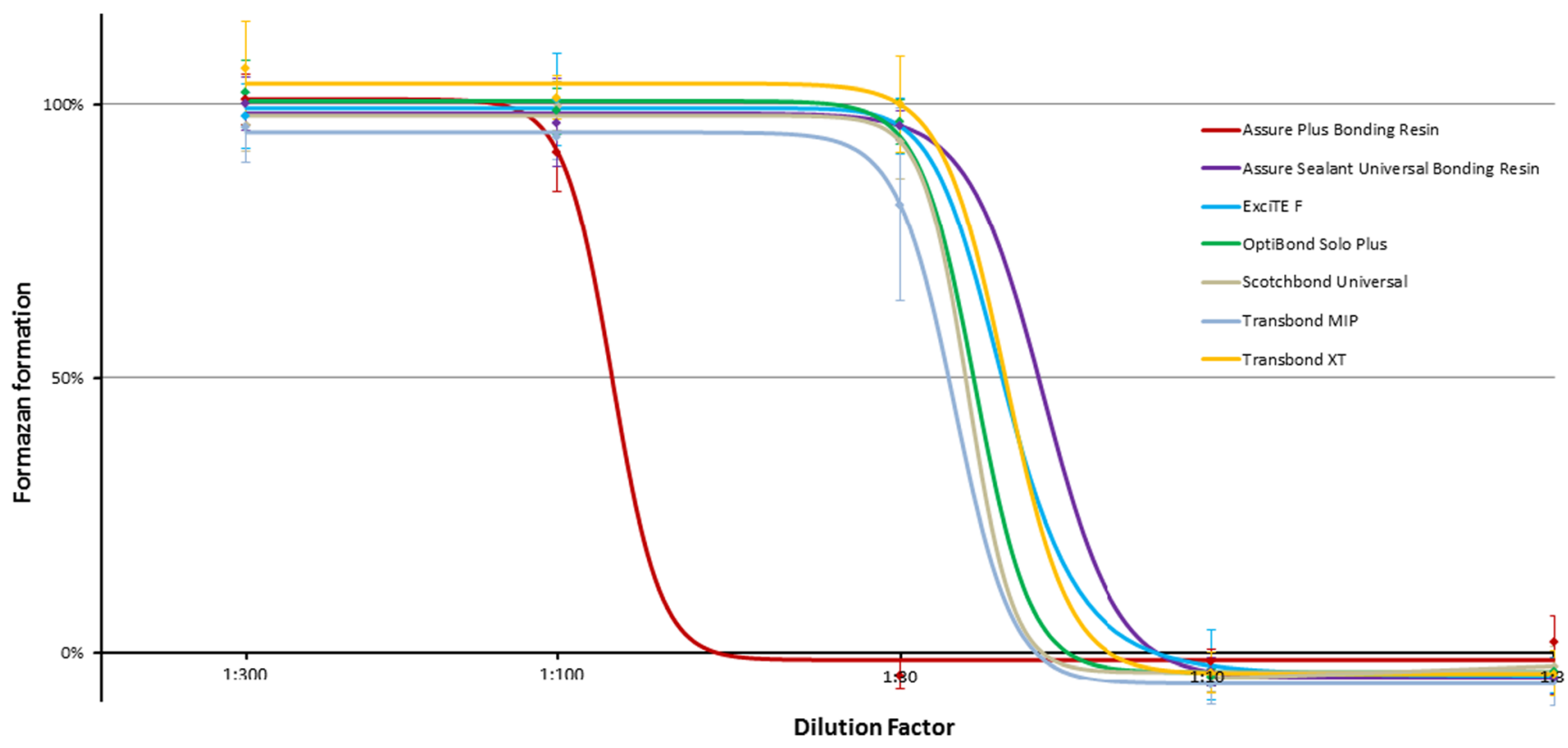

Fig. 1 Dose response curve for cell viability after treatment of hGfs with different dilutions of adhesives. The sigmoidal curve is the result of the computation via a four-point logistic function to estimate the effective concentration (EC50). The EC50 represents the dilution factor corresponding to the half maximum effect in terms of formazan formation

cavity. A dilution of the prepared stock solution by the factor of 1:20 was set as a starting concentration with subsequent dilutions by a factor of 3, testing 1:60 and 1:180 dilutions, respectively.

The $\gamma \mathrm{H} 2 \mathrm{AX}$ foci numbers in the samples incubated with the highest adhesive concentrations (1:20) were for Assure Plus $2.7 \pm 1.1$ (mean $\pm \mathrm{SDM}$ ), for Assure Sealant 8.6 \pm 1.2 , for Excite F 9.3 \pm 2.9 , for Optibond Solo Plus 2.5 \pm 1 , for Scotchbond Universal $6 \pm 1$, for Transbond MIP $20.3 \pm 2.2$, and for Transbond XT $7 \pm 2.4$. A positive control was $1-\mathrm{mM}$ MMS, for which $12 \pm 3.3$ foci/cell were determined (see (Fig. 3 and Fig. 4)). Untreated control cells displayed on average $2.8 \pm 1$ foci per cell. For most of the samples, the largest amount of induced $\gamma \mathrm{H} 2 \mathrm{AX}$ foci was measured when the compared with the control (Table 1). The mean levels of formazan formation in cells treated with the respective dilution of different adhesives after $24 \mathrm{~h}$ of exposure is shown as diamonds. The presented values have been normalized to untreated control cells $(n \geq 6)$. Error bars represent the standard deviation of the mean (SDM)

highest concentration of the monomers was used for treatment.

Only for products Assure Plus and Optibond, the highest foci numbers were not detected in the sample with the highest concentration. For Assure Plus, a significant increase in the foci level compared with the control could only be detected in the samples with the higher dilution rates, with $3.9 \pm 1.2$ at $1: 60$ and $3.7 \pm 0.5$ at $1: 180$. For Optibond Solo Plus, the highest number of foci could be detected in the 1:60 sample $(10.5 \pm 2.4)$. The highest level of focus induction was observed in the samples treated with the highest concentration of Transbond MIP (20.3 \pm 2.2 ), indicating Transbond MIP has the highest genotoxic potential.
Table 2 Effective concentration and relative toxicity (means of the EC50 values) of the tested dental adhesives

\begin{tabular}{lll}
\hline Product & Effective concentration EC50 \pm SDM & Relative toxicity \\
\hline Assure Sealant Universal Bonding Resin * & $17.9 \pm 4.3$ & 1 \\
Transbond XT * $^{*}$ & $20.2 \pm 4.5$ & 1.13 \\
Scotchbond Universal Adhesive * $^{*}$ & $20.6 \pm 3.9$ & 1.15 \\
ExciTE F & $22.1 \pm 2.6$ & 1.23 \\
OptiBond Solo Plus * $_{\text {Transbond MIP * }}^{*}$ & $22.7 \pm 1.6$ & 1.27 \\
Assure Plus Bonding Resin & $23.8 \pm 3.3$ & 1.33 \\
\hline
\end{tabular}

* Significantly different than Assure Plus Bonding Resin $(p \leq 0.05)$

For the specimen Assure Sealant, Excite F, Optibond Solo, Scotchbond Universal, Transbond MIP, Transbond XT six experiments were performed $(n=6)$ and for Assure Plus nine experiments were carried out $(n=9)$ 
Fig. 2 Human gingival fibroblasts $24 \mathrm{~h}$ after incubation with dilutions of dental adhesives. Staining was performed in accordance with the Live/Dead assay. Calcein stains living cells with intracellular esterase activity fluorescent green due to enzymatic conversion. Ethidium homodimer intercalates into DNA of dead or dying cells, causing a red fluorescent signal, while being excluded from living cells. Live/ Dead cells and morphology were evaluated to validate the estimated effective concentration (EC50) of the material $(n=3)$

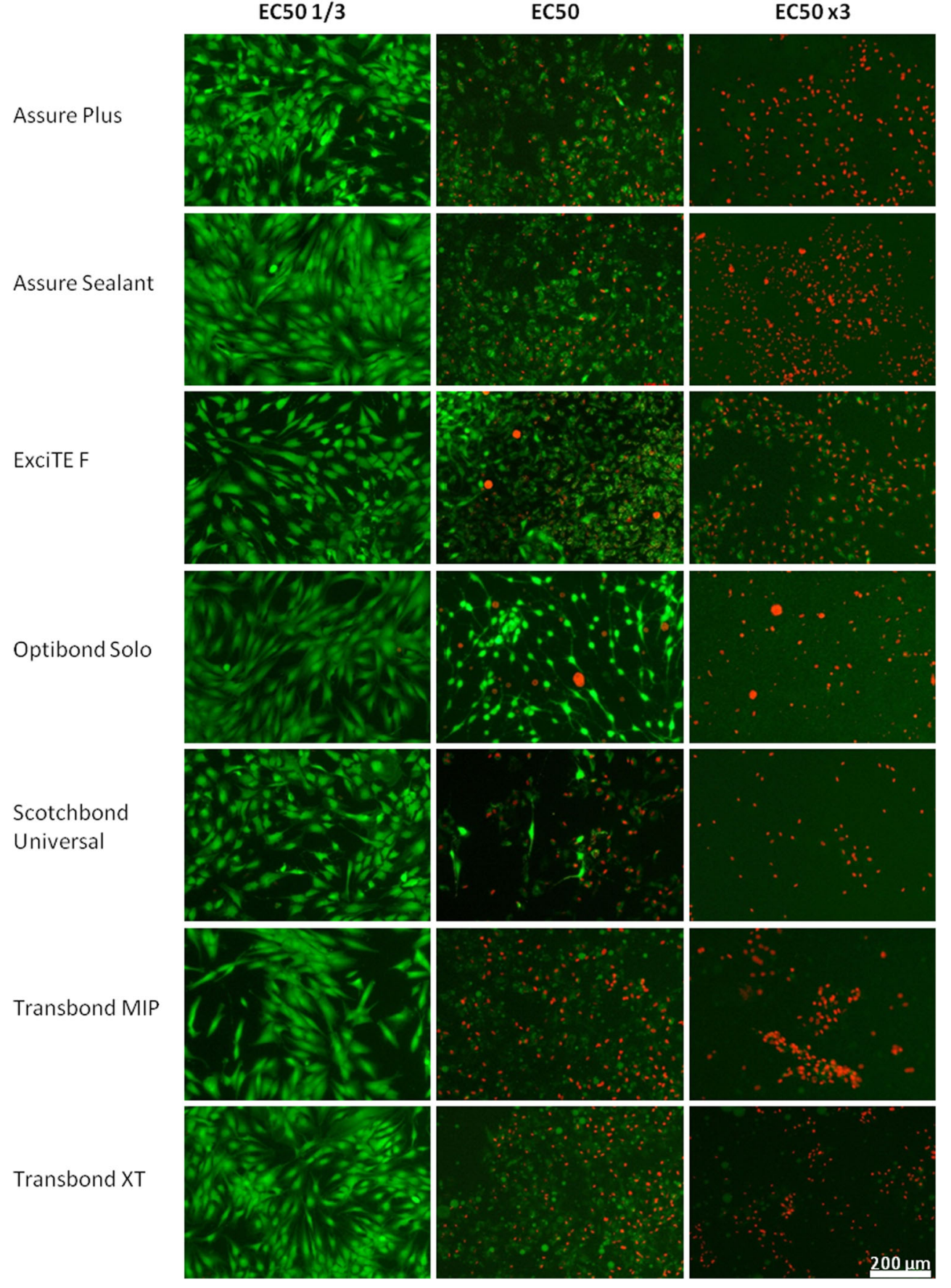

\section{Discussion}

The DNA double strand break is considered to be the most dangerous lesion impacting a cell's genomic integrity. A well-orchestrated system of DNA damage sensors, signal transmitters, and executors either inhibit cell cycle progression and provide sufficient time for DNA damage repair or induce apoptosis in order to prevent transformation into a cancer cell. The key factors for DNA damage recognition are the kinases ATM and ATR, which phosphorylate and therefore activate subsequent proteins and induce the DNA damage response, with $\mathrm{p} 53$ playing a pivotal role [32]. Whether the DNA damage response machinery is activated by double-strand breaks or indirectly by stalled replication forks, one of the very early reactions to these insults is the phosphorylation of the histone subvariant $\mathrm{H} 2 \mathrm{AX}$ into $\gamma \mathrm{H} 2 \mathrm{AX}$ conducted by the kinases ATM and ATR. Both kinases facilitate the regulation of $\mathrm{p} 53$, the so-called guardian of the genome, either by direct or indirect interaction via mediating kinases. 


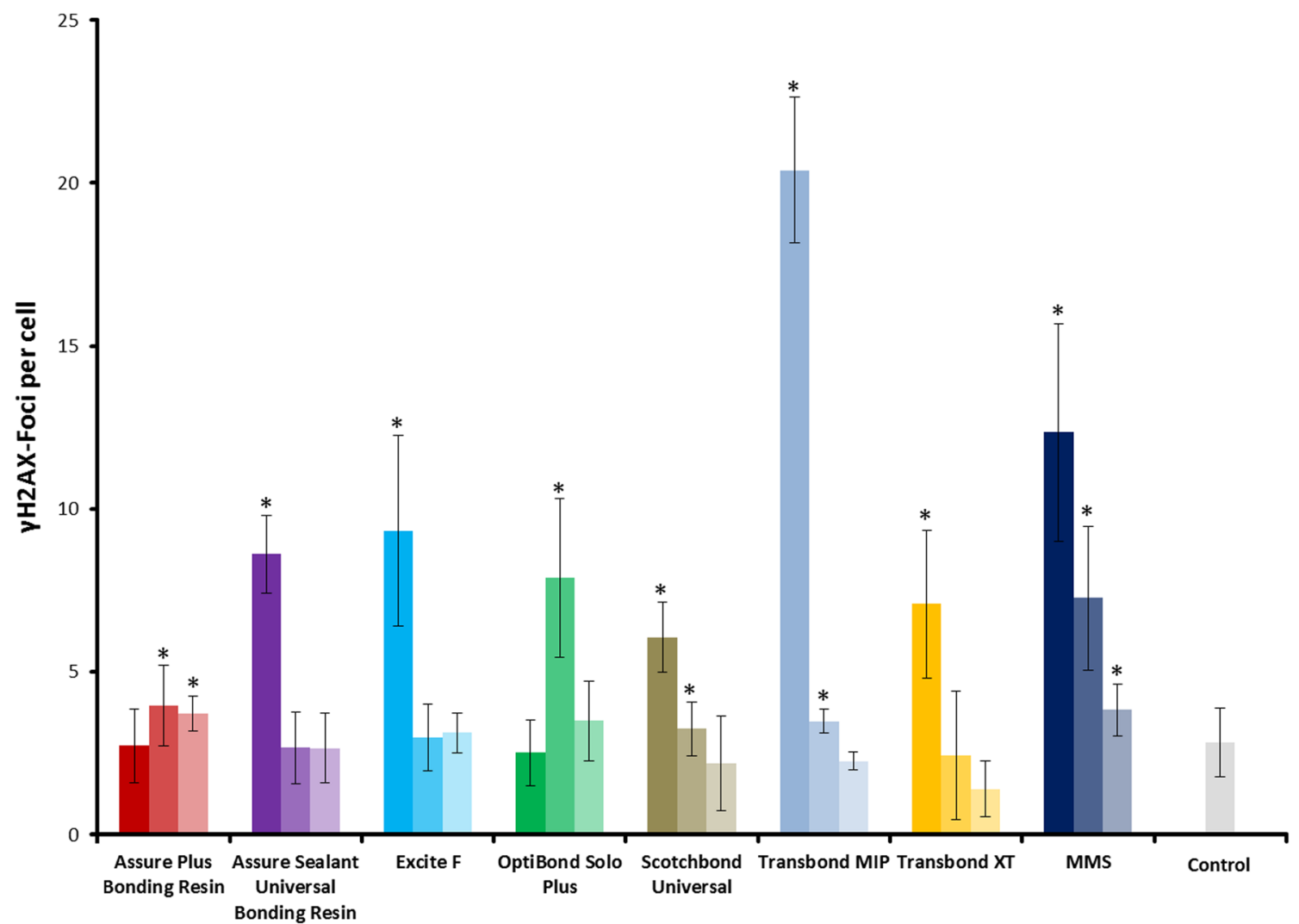

Fig. 3 Induction of $\gamma \mathrm{H} 2 \mathrm{AX}$ foci in human gingival fibroblasts after $6 \mathrm{~h}$ of incubation with different methacrylate-based adhesives. The color shading refers to the different concentrations used, corresponding to 1:20, $1: 60$, and $1: 180$ for the adhesives and $1 \mathrm{mM}, 0.3 \mathrm{mM}$, and $0.1 \mathrm{mM}$ of methyl methanesulfonate (MMS) as a positive control, respectively. The highest concentration is depicted as saturated color, and lower concentrations are indicated by lighter shades of the corresponding color. The columns represent the mean values with the standard deviation of the mean between experiments (SDM). Data from three independent experiments each analyzing 80 nuclei are shown $(n=240)$. Asterisks highlight significant differences compared with the control $(p \leq 0.05)$
Most of the findings regarding the discrimination of genotoxic or non-genotoxic compounds inducing cytotoxic effects can be applied to isolated substances. Therefore, discriminating a mixture of several known genotoxicants and/or non-genotoxicans with regard to their cytotoxicity is complex. Both cytotoxicities due to preceding DNA damage and direct cytotoxic events are involved, while other damaging mechanisms leading to apoptosis, necroptosis, or necrosis have to be taken into account as well.

The present study was conducted to investigate the cytotoxicity and the genotoxic potential of seven commercially available orthodontic methacrylate-based, lightcured adhesives using the XTT, the Live/Dead assay, and $\gamma \mathrm{H} 2 \mathrm{AX}$ assay, respectively. Since the isolated adhesive compounds, predominantly methacrylate monomers, were shown to impact the genomic integrity, we addressed the question of whether methacrylate-based products of varying composition exert a risk regarding the induction of DNA damage. Several oral cell culture models attested that monomers such as BisGMA, HEMA, TEGDMA, and UDMA showed elevated cytotoxicity and induced oxidative stress, i.e., ROS formation [17, 26, 33-36].

The small monomer HEMA has hydrophilic properties and is therefore frequently added to adhesives to ensure good wetting of dental surfaces and further enhances handling when combined with hydrophobic or highly viscous monomers like BisGMA [37].

HEMA induces oxidative stress accompanied with reduced cell viability due to depletion of the cytoprotective metabolite GSH. The reversal of the particular phenotype by antioxidants acting as ROS scavengers like $\mathrm{N}$-acetylcysteine, ascorbate, or melatonin is underlining that ROS formation is key to a decreasing cell survival $[19,22,38]$. The dose-dependent increase of the cleavage of pro-caspase 3 , yielding the critical apoptosis effector caspase 3, adds further evidence to the hypothesis of an apoptosis-dependent decrease in cell viability [38]. The disruption of the mitochondrial membrane potential in cell cultures incubated with HEMA suggests that resin monomer-induced programmed cell death can be mediated through the intrinsic mitochondrial pathway of apoptosis [38]. Additionally, p53-dependent pathways of apoptosis 
Fig. 4 Representative images of $\gamma \mathrm{H} 2 \mathrm{AX}$ focus staining in fixed human gingival fibroblasts. The cells were treated with the indicated dilution of the adhesive supernatant for $6 \mathrm{~h}$. As positive control, cells were treated with the indicated concentrations of the genotoxin methyl methanesulfonate (MMS) for $1 \mathrm{~h}$ followed by $6 \mathrm{~h}$ recovery. $\gamma \mathrm{H} 2 \mathrm{AX}$ foci are depicted in green. Nuclear counterstaining was performed with DAPI and is depicted in blue. Control, nontreated cells
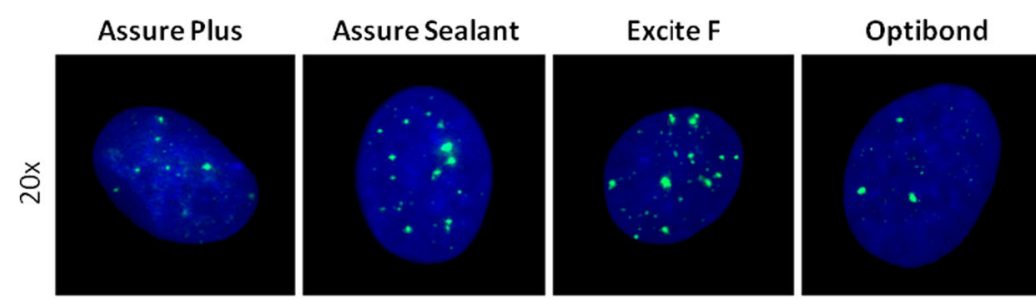

Scotchbond
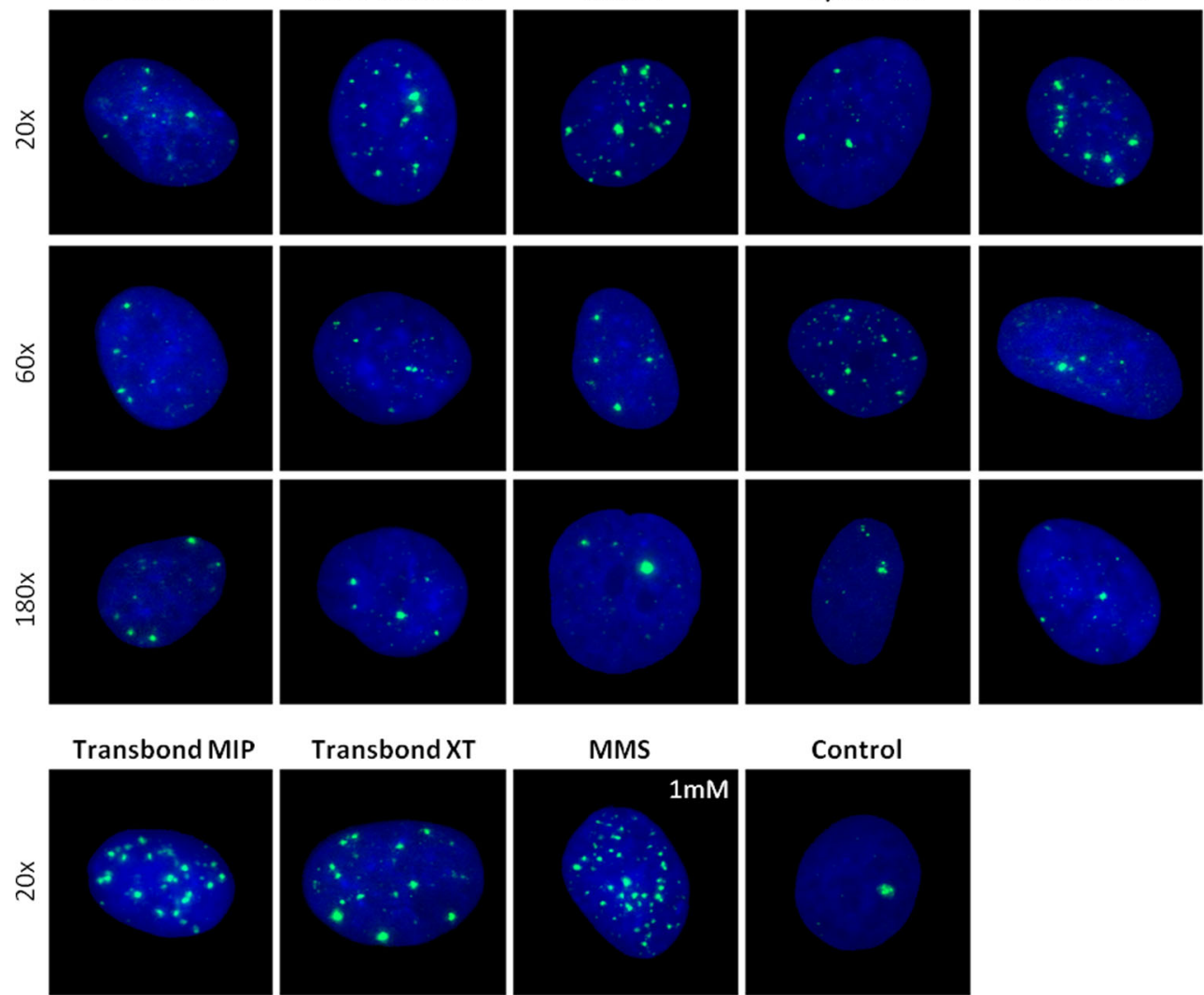

Transbond XT

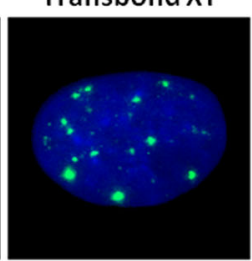

MMS

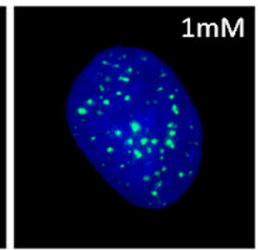

Control
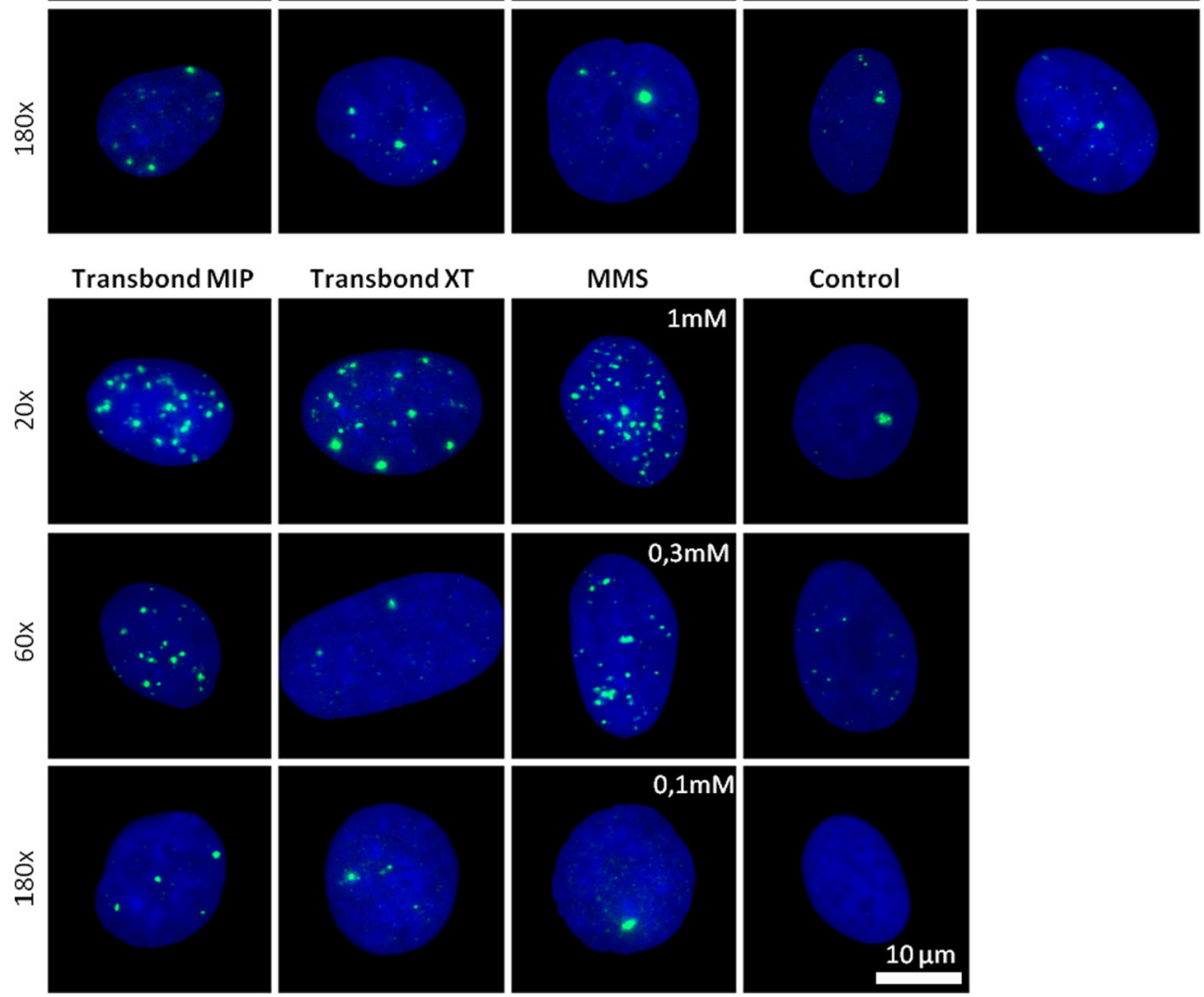

have been shown for HEMA. Earlier reports indicated the formation of DNA double-strand breaks in HEMA exposed cells $[17,18]$, leading to genotoxic or mutagenic events most likely based on oxidative DNA damage [39].

In general, the cytotoxic potential of a monomer is dependent on its specification and the respective dose employed. As DNA double-strand breaks can lead to apoptosis, the amount of detected $\gamma \mathrm{H} 2 \mathrm{AX}$ foci directly correlates with a reduction of viability of the treated cells. Monomers such as BisGMA, UDMA, TEGDMA, and HEMA show differences in terms of cytotoxicity and genotoxicity, with the most severe effects found in BisGMA, followed by UDMA, TEGDMA, and HEMA [17]. It was assumed before that these differences can be attributed to different liposolubility, with BisGMA sharing the highest liposolubility and enabling a more effective cell penetration [17]. In addition to a ROS- dependent mechanism of DNA damage induction, epoxy methacrylates have been detected in methacrylate-treated cells as well [40, 41]. The assumption that methacrylate monomers are metabolized into epoxy compounds and exert a direct DNA damage induction has been recently substantiated [17, 23]. Throughout the present study, we used primary gingival fibroblasts, which represent a potential target for the monomers mentioned above. First, we assessed human fibroblasts incubated with liquid adhesives and observed a reduction in cell viability to various extent. Morphological aspects typical of apoptosis such as pseudopod retraction, rounding up of the cells and a decreased cellular volume (pyknosis) were 
observed at concentrations determined to be cytotoxic in the XTT assay. These results are in accordance with previous reports on dental adhesive methacrylates $[16,26]$. The resulting DNA damage can be detected by the comet assay, micronucleus assay, chromosomal aberration, sisterchromatid exchange, and the $\gamma \mathrm{H} 2 \mathrm{AX}$ assay, all of which are used to analyze different genotoxic end points [42]. Here, we utilized the $\gamma \mathrm{H} 2 \mathrm{AX}$ foci assay and assessed the genotoxicity of the materials by comparing the adhesive materials at the same dose level as to its ability to induce DNA damage. It is worth mentioning that the XTT or Live/Dead assay and the $\gamma \mathrm{H} 2 \mathrm{AX}$ assay require different incubation times. The XTT assay investigates cells after an incubation period of $24 \mathrm{~h}$, while the $\gamma \mathrm{H} 2 \mathrm{AX}$ assay examines cells after $6 \mathrm{~h}$ of exposure to the diluted adhesive. The early $\gamma \mathrm{H} 2 \mathrm{AX}$ detection allows an assessment even though the dose applied could be cytotoxic. This feature is of particular importance since in late apoptotic stages, e.g., nuclear fragments or micronuclei; the $\gamma \mathrm{H} 2 \mathrm{AX}$ signal is not always linked to a DSB induced by the agent in question [16]. Thus, apoptotic events may have an impact on the proper detection of $\gamma \mathrm{H} 2 \mathrm{AX}$ foci. Furthermore, strong pan nuclear $\gamma \mathrm{H} 2 \mathrm{AX}$ staining was shown to result from massive DNA cleavage due to caspase-activated nuclease [43, 44]. To avoid mistaking those events for one another, only intact nuclei were evaluated, and cells exhibiting pan nuclear $\gamma \mathrm{H} 2 \mathrm{AX}$ staining were excluded from the analysis. For AP, we observed no increase in $\gamma \mathrm{H} 2 \mathrm{AX}$ foci formation at high-dose levels. This could be due to cell cycle perturbations. Although vital cells were still present after treatment, the cells could be arrested in specific cell cycle phases, preventing from the formation of DSBs, and therefore $\gamma \mathrm{H} 2 \mathrm{AX}$ foci. This might lead to cell cycle-specific killing of cells in vulnerable cell cycle phases, such as the S-phase. Evidence for this assumption has been previously presented in a report on cell cycle effects of dental adhesives on human gingival fibroblasts [19]. The adhesives induced an increase in the $\mathrm{G} 1 / \mathrm{G} 0$ and $\mathrm{G} 2 / \mathrm{M}$ populations, which was accompanied by a depletion of the Sphase population. When examining the composition of Assure Plus, attention is drawn to 10-methacryloyldodeylphosphate (10-MDP), a compound that is solely present in this adhesive. The 10-MDP represents a functional monomer with a selfetch function, which is able to form a stable calcium salt, and thereby adhere to enamel surfaces. It has been reported that impurities in different 10-MDP formulas influence the biocompatibility of the material [45]. However, in our setting, whether the compound itself or potential impurities were responsible for its cytotoxic potential remained elusive. The pronounced cytotoxicity of OptiBond Solo likely diminished the amount of evaluable viable or actively cycling cells, and therefore interfered with the proper detection of $\gamma \mathrm{H} 2 \mathrm{AX}$ at the highest concentration. Considering the Live/Dead assay, the growth pattern of the monolayer as well as the cell morphology suggested an elevated cytotoxicity of the adhesive associated with rounding up of the cells. The remaining cell membrane integrity might provide a hint concerning why the level of cytotoxicity was not portrayed to the same extent by the XTT assay, despite ongoing apoptotic processes. Likewise, the most prominent increase in $\gamma \mathrm{H} 2 \mathrm{AX}$ focus induction as observed at lower adhesive concentrations.

For Assure Sealant, Excite F, Scotchbond Universal, and Transbond XT, which show comparable cytotoxicity in the XTT and Live/Dead assay, a linear relationship between the adhesive concentration and $\gamma \mathrm{H} 2 \mathrm{AX}$ focus induction was apparent. However, Transbond MIP, the cytotoxicity of which is comparable with the aforementioned adhesives, was distinguished by a significant increase in $\mathrm{yH} 2 \mathrm{AX}$ numbers.

While the photoinitiator camphorquinone (CQ) was listed in two samples, the co-initiator diphenyliodonium hexafluorophosphate (DPIHP), an iodonium salt releasing the active compound diphenyliodonium (DPI), was only listed for Transbond MIP. For DPI, the intracellular mode of action in terms of ROS induction seems to be paradox, since both the stimulation and the inhibition of ROS have been reported in literature [46-48]. The potential of DPI as an inhibitor of the NADPH oxidase with subsequent diminishment of ROS production on the one hand and the disturbance of the cellular redox balance including depletion of the GSH pool on the other hand suggests a concentration-dependent mode of action, with a shift toward induction of oxidative stress at higher concentrations. Another DNA damaging mechanism has been proposed for DPI as well, via the acceptance of an electron at redox centers like the aforementioned NADPH oxidase and thereby turning into a phenyl radical [47]. The radical itself harbors the potential to directly damage the DNA, with the subsequent activation of the DNA damage repair machinery. DPIHP, which is added to increase the degree of conversion, is usually accompanied by CQ, which has been shown to exert genotoxic potential by itself [49-51]. Even though the total mass of DPIHP, which is below $1 \%$, does not significantly alter the cytotoxic properties of Transbond MIP, it most likely evokes $\gamma \mathrm{H} 2 \mathrm{AX}$ foci. A high genotoxic potential of diphenyliodonium chloride (DPIC), a substance closely related to DPIHP, has been previously reported based on the $\gamma \mathrm{H} 2 \mathrm{AX}$ assay [24]. Furthermore, the genotoxic activity of the substance itself and/or its degradation into halogenated benzenes has been mentioned [52]. Not surprisingly, the presence of the degradation product iodobenzene, as detected by gas chromatography [53], may be linked to the use of DPIHP. Nonetheless, DPIC and DPIHP share characteristics that seem to have a significant impact on their genotoxic properties. A putative synergistic effect of methacrylates, CQ and/or other additives in terms of ROS, and induction of DNA damage has been previously suggested [33].

Therefore, regarding the cytotoxic/genotoxic potential of a product, not only the manufacturer's list of chemical composition must be taken into account but also the residues derived 
from the synthesis of the raw materials, which may affect the biocompatibility of the product in a negative manner. Therefore, all chemicals with a potential to exert endocrine activity, cytotoxicity, genotoxicity, and allergic reactions should be listed in the product safety profile [53-56]. In orthodontic treatment, a major exposition to monomers occurs during the application of brackets at the beginning of multiband therapy. The use of a rubber dam has long been advocated for orthodontic purposes since it can minimize the direct contact of unpolymerized adhesive with the buccal/oral mucosa and reduce systemic uptake [57]. Thorough air suction appears to be beneficial for patients as well as for the dental staff since the distribution, ingestion, and inhalation of free aerosol can be minimized. Since the long-term effects and accompanying safety issues remain unclear, the application of adhesives should be performed using the considered amounts, as excess material must be thoroughly removed and contact with the gingival, subgingival, and interproximal tissues must be avoided [11].

The use in dental practice of HEMA- and TEGDMA-free adhesives, e.g., silorane-based adhesives, which seem to be superior with respect to biocompatibility, has recently been suggested [39]. Regardless, a methacrylate-free product may still be dependent on common photoinitiating additives, such as CQ, DPIC, or DPIHP, which also need to be considered when assessing biosafety in terms of genotoxicity.

\section{Conclusions}

Doubts regarding the biosafety of orthodontic adhesives have been raised due to the increasing number of reports addressing the leaching and cytotoxic and genotoxic properties of single ingredients. Therefore, it seemed reasonable to compare orthodontic adhesives in terms of their genotoxic and cytotoxic potential, both of which are closely related. Differences regarding the genotoxic potential were further elucidated with respect to single components conceivably responsible for the genotoxic effects observed. The DNA-damaging capability of adhesives was assessed with the notion that the co-initiator DPIHP likely has an additive effect on the $\gamma \mathrm{H} 2 \mathrm{AX}$ focus formation induced by methacrylate monomers like HEMA, TEGDMA, UDMA, and BisGMA. Therefore, DPIHP may enhance the genotoxicity of a compound. This compelling presumption will be subject of future investigations. The clinical relevance of the cytotoxic and genotoxic properties of orthodontic adhesives remains unclear due to the short exposure time and sharp decline in concentration resulting from dilution effects in the aqueous environment.

Acknowledgments The data from this study are part of the doctoral thesis of Andreas Taubmann, as submitted to the Johannes Gutenberg
University of Mainz. We thank Claudia Darmstadt for excellent technical assistance.

Funding Open Access funding enabled and organized by Projekt DEAL.

\section{Compliance with ethical standards}

Conflict of interest The authors declare that they have no conflict of interest.

Ethical approval This article does not contain any studies with human participants or animals performed by any of the authors.

Informed consent For this type of study, formal consent is not required.

Open Access This article is licensed under a Creative Commons Attribution 4.0 International License, which permits use, sharing, adaptation, distribution and reproduction in any medium or format, as long as you give appropriate credit to the original author(s) and the source, provide a link to the Creative Commons licence, and indicate if changes were made. The images or other third party material in this article are included in the article's Creative Commons licence, unless indicated otherwise in a credit line to the material. If material is not included in the article's Creative Commons licence and your intended use is not permitted by statutory regulation or exceeds the permitted use, you will need to obtain permission directly from the copyright holder. To view a copy of this licence, visit http://creativecommons.org/licenses/by/4.0/.

\section{References}

1. Miura F, Nakagawa K, Masuhara E (1971) New direct bonding system for plastic brackets. Am J Orthod 59:350-361

2. Newman GV (1965) Epoxy adhesives for orthodontic attachments: progress report. Am J Orthod 51:901-912

3. Gange P (2015) The evolution of bonding in orthodontics. Am J Orthod Dentofacial Orthop 147:S56-S63. https://doi.org/10.1016/j. ajodo.2015.01.011

4. Paul W (2013) Bonding techniques in lingual orthodontics. J Orthod 40 Supp1 1:S20-S26. https://doi.org/10.1179/ 1465313313 y.0000000060

5. Turner PJ (1996) Successful bonding in orthodontics: 1. Dent Update 23:366-370

6. Williams DF (2008) On the mechanisms of biocompatibility. Biomaterials 29:2941-2953. https://doi.org/10.1016/j. biomaterials.2008.04.023

7. Malkiewicz K, Turlo J, Marciniuk-Kluska A, Grzech-Lesniak K, Gasior M, Kluska M (2015) Release of bisphenol a and its derivatives from orthodontic adhesive systems available on the European market as a potential health risk factor. Ann Agric Environ Med 22: 172-177. https://doi.org/10.5604/12321966.1141390

8. Hensten-Pettersen A (1998) Skin and mucosal reactions associated with dental materials. Eur J Oral Sci 106:707-712

9. Stanley HR (1993) Effects of dental restorative materials: local and systemic responses reviewed. J Am Dent Assoc 124:76-80

10. Tang AT, Liu Y, Bjorkman L, Ekstrand J (1999) In vitro cytotoxicity of orthodontic bonding resins on human oral fibroblasts. Am J Orthod Dentofac Orthop 116:132-138

11. Jagdish N, Padmanabhan S, Chitharanjan AB, Revathi J, Palani G, Sambasivam M, Sheriff K, Saravanamurali K (2009) Cytotoxicity and degree of conversion of orthodontic adhesives. Angle Orthod 79:1133-1138. https://doi.org/10.2319/080808-418r.1 
12. Demirci M, Hiller KA, Bosl C, Galler K, Schmalz G, Schweikl H (2008) The induction of oxidative stress, cytotoxicity, and genotoxicity by dental adhesives. Dent Mater 24:362-371. https:// doi.org/10.1016/j.dental.2007.06.009

13. Gölz L, Simonis RA, Reichelt J, Stark H, Frentzen M, Allam JP, Probstmeier R, Winter J, Kraus D (2016) In vitro biocompatibility of ICON(®) and TEGDMA on human dental pulp stem cells. Dent Mater 32:1052-1064. https://doi.org/10.1016/j.dental.2016.06.002

14. Mantellini MG, Botero TM, Yaman P, Dennison JB, Hanks CT, Nor JE (2003) Adhesive resin induces apoptosis and cell-cycle arrest of pulp cells. J Dent Res 82:592-596. https://doi.org/10. $1177 / 154405910308200804$

15. Rakich DR, Wataha JC, Lefebvre CA, Weller RN (1999) Effect of dentin bonding agents on the secretion of inflammatory mediators from macrophages. J Endod 25:114-117. https://doi.org/10.1016/ s0099-2399(99)80008-9

16. Styllou P, Styllou M, Hickel R, Hogg C, Reichl FX, Scherthan H (2017) NAC ameliorates dental composite-induced DNA doublestrand breaks and chromatin condensation. Dent Mater J 36:638646. https://doi.org/10.4012/dmj.2016-316

17. Urcan E, Scherthan H, Styllou M, Haertel U, Hickel R, Reichl FX (2010) Induction of DNA double-strand breaks in primary gingival fibroblasts by exposure to dental resin composites. Biomaterials 31 : 2010-2014. https://doi.org/10.1016/j.biomaterials.2009.11.065

18. Ansteinsson V, Solhaug A, Samuelsen JT, Holme JA, Dahl JE (2011) DNA-damage, cell-cycle arrest and apoptosis induced in BEAS-2B cells by 2-hydroxyethyl methacrylate (HEMA). Mutat Res 723:158-164. https://doi.org/10.1016/j.mrgentox.2011.04.011

19. Blasiak J, Synowiec E, Tarnawska J, Czarny P, Poplawski T, Reiter RJ (2012) Dental methacrylates may exert genotoxic effects via the oxidative induction of DNA double strand breaks and the inhibition of their repair. Mol Biol Rep 39:7487-7496. https://doi.org/10. 1007/s11033-012-1582-3

20. Schweikl H, Spagnuolo G, Schmalz G (2006) Genetic and cellular toxicology of dental resin monomers. J Dent Res 85:870-877

21. Lobrich M, Shibata A, Beucher A, Fisher A, Ensminger M, Goodarzi AA, Barton O, Jeggo PA (2010) gammaH2AX foci analysis for monitoring DNA double-strand break repair: strengths, limitations and optimization. Cell Cycle 9:662-669. https://doi. org/10.4161/cc.9.4.10764

22. Lottner S, Shehata M, Hickel R, Reichl FX, Durner J (2013) Effects of antioxidants on DNA-double strand breaks in human gingival fibroblasts exposed to methacrylate based monomers. Dent Mater 29:991-998. https://doi.org/10.1016/i.dental.2013.07.005

23. Yang Y, Reichl FX, Shi J, He X, Hickel R, Hogg C (2018) Cytotoxicity and DNA double-strand breaks in human gingival fibroblasts exposed to eluates of dental composites. Dent Mater 34:201-208. https://doi.org/10.1016/j.dental.2017.10.002

24. Shehata M, Durner J, Eldenez A, Van Landuyt K, Styllou P, Rothmund L, Hickel R, Scherthan H, Geurtsen W, Kaina B, Carell T, Reichl FX (2013) Cytotoxicity and induction of DNA double-strand breaks by components leached from dental composites in primary human gingival fibroblasts. Dent Mater 29:971-979. https://doi.org/10.1016/j.dental.2013.07.007

25. Nikolova T, Dvorak M, Jung F, Adam I, Kramer E, Gerhold-Ay A, Kaina B (2014) The gammaH2AX assay for genotoxic and nongenotoxic agents: comparison of $\mathrm{H} 2 \mathrm{AX}$ phosphorylation with cell death response. Toxicol Sci 140:103-117. https://doi.org/10. 1093/toxsci/kfu066

26. Styllou M, Reichl FX, Styllou P, Urcan E, Rothmund L, Hickel R, Hogg C, Scherthan H (2015) Dental composite components induce DNA-damage and altered nuclear morphology in gingiva fibroblasts. Dent Mater 31:1335-1344. https://doi.org/10.1016/j.dental. 2015.08 .156

27. Liu X, Wang J, Dong F, Li H, Hou Y (2016) Human gingival fibroblasts induced and differentiated into vascular endothelial- like cells. Develop Growth Differ 58:702-713. https://doi.org/10. $1111 /$ dgd. 12327

28. Sancilio S, di Giacomo V, Di Giulio M, Gallorini M, Marsich E, Travan A, Tarusha L, Cellini L, Cataldi A (2014) Biological responses of human gingival fibroblasts (HGFs) in an innovative coculture model with Streptococcus mitis to thermosets coated with a silver polysaccharide antimicrobial system. PLoS One 9:e96520. https://doi.org/10.1371/journal.pone.0096520

29. Berridge MV, Herst PM, Tan AS (2005) Tetrazolium dyes as tools in cell biology: new insights into their cellular reduction. Biotechnol Annu Rev 11:127-152. https://doi.org/10.1016/s13872656(05)11004-7

30. Scudiero DA, Shoemaker RH, Paull KD, Monks A, Tierney S, Nofziger TH, Currens MJ, Seniff D, Boyd MR (1988) Evaluation of a soluble tetrazolium/formazan assay for cell growth and drug sensitivity in culture using human and other tumor cell lines. Cancer Res 48:4827-4833

31. Sebaugh JL (2011) Guidelines for accurate EC50/IC50 estimation. Pharm Stat 10:128-134. https://doi.org/10.1002/pst.426

32. Roos WP, Kaina B (2013) DNA damage-induced cell death: from specific DNA lesions to the DNA damage response and apoptosis. Cancer Lett 332:237-248. https://doi.org/10.1016/j.canlet.2012.01. 007

33. Engelmann J, Janke V, Volk J, Leyhausen G, von Neuhoff N, Schlegelberger B, Geurtsen W (2004) Effects of BisGMA on glutathione metabolism and apoptosis in human gingival fibroblasts in vitro. Biomaterials 25:4573-4580. https://doi.org/10.1016/j. biomaterials.2003.11.048

34. Engelmann J, Volk J, Leyhausen G, Geurtsen W (2005) ROS formation and glutathione levels in human oral fibroblasts exposed to TEGDMA and camphorquinone. J Biomed Mater Res B Appl Biomater 75:272-276. https://doi.org/10.1002/jbm.b.30360

35. Goldberg M (2008) In vitro and in vivo studies on the toxicity of dental resin components: a review. Clin Oral Investig 12:1-8. https://doi.org/10.1007/s00784-007-0162-8

36. Stanislawski L, Lefeuvre M, Bourd K, Soheili-Majd E, Goldberg M, Perianin A (2003) TEGDMA-induced toxicity in human fibroblasts is associated with early and drastic glutathione depletion with subsequent production of oxygen reactive species. J Biomed Mater Res A 66:476-482. https://doi.org/10.1002/jbm.a.10600

37. Van Landuyt KL, Snauwaert J, De Munck J, Peumans M, Yoshida Y, Poitevin A, Coutinho E, Suzuki K, Lambrechts P, Van Meerbeek B (2007) Systematic review of the chemical composition of contemporary dental adhesives. Biomaterials 28:3757-3785. https://doi.org/10.1016/j.biomaterials.2007.04.044

38. Schweikl H, Petzel C, Bolay C, Hiller KA, Buchalla W, Krifka S (2014) 2-Hydroxyethyl methacrylate-induced apoptosis through the ATM- and p53-dependent intrinsic mitochondrial pathway. Biomaterials 35:2890-2904. https://doi.org/10.1016/j. biomaterials.2013.12.044

39. Krifka S, Seidenader C, Hiller KA, Schmalz G, Schweikl H (2012) Oxidative stress and cytotoxicity generated by dental composites in human pulp cells. Clin Oral Investig 16:215-224. https://doi.org/ 10.1007/s00784-010-0508-5

40. Reichl FX, Durner J, Hickel R, Kunzelmann KH, Jewett A, Wang MY, Spahl W, Kreppel H, Moes GW, Kehe K, Walther U, Forth W, Hume WR (2001) Distribution and excretion of TEGDMA in guinea pigs and mice. J Dent Res 80:1412-1415. https://doi.org/10. $1177 / 00220345010800050501$

41. Seiss M, Nitz S, Kleinsasser N, Buters JT, Behrendt H, Hickel R, Reichl FX (2007) Identification of 2,3-epoxymethacrylic acid as an intermediate in the metabolism of dental materials in human liver microsomes. Dent Mater 23:9-16. https://doi.org/10.1016/j.dental. 2005.11.038

42. Ginzkey C, Zinnitsch S, Steussloff G, Koehler C, Hackenberg S, Hagen R, Kleinsasser NH, Froelich K (2015) Assessment of 
HEMA and TEGDMA induced DNA damage by multiple genotoxicological endpoints in human lymphocytes. Dent Mater 31:865-876. https://doi.org/10.1016/j.dental.2015.04.009

43. Meyer B, Voss KO, Tobias F, Jakob B, Durante M, Taucher-Scholz G (2013) Clustered DNA damage induces pan-nuclear H2AX phosphorylation mediated by ATM and DNA-PK. Nucleic Acids Res 41:6109-6118. https://doi.org/10.1093/nar/gkt304

44. Solier S, Pommier Y (2009) The apoptotic ring: a novel entity with phosphorylated histones $\mathrm{H} 2 \mathrm{AX}$ and $\mathrm{H} 2 \mathrm{~B}$ and activated DNA damage response kinases. Cell Cycle 8:1853-1859. https://doi.org/10. 4161/cc.8.12.8865

45. Yoshihara K, Nagaoka N, Okihara T, Kuroboshi M, Hayakawa S, Maruo Y, Nishigawa G, De Munck J, Yoshida Y, Van Meerbeek B (2015) Functional monomer impurity affects adhesive performance. Dent Mater 31:1493-1501. https://doi.org/10.1016/j. dental.2015.09.019

46. Li Y, Trush MA (1998) Diphenyleneiodonium, an NAD(P) H oxidase inhibitor, also potently inhibits mitochondrial reactive oxygen species production. Biochem Biophys Res Commun 253:295-299. https://doi.org/10.1006/bbrc.1998.9729

47. O'Donnell VB, Smith GC, Jones OT (1994) Involvement of phenyl radicals in iodonium inhibition of flavoenzymes. Mol Pharmacol 46:778-785

48. Riganti C, Gazzano E, Polimeni M, Costamagna C, Bosia A, Ghigo D (2004) Diphenyleneiodonium inhibits the cell redox metabolism and induces oxidative stress. J Biol Chem 279:47726-47731. https://doi.org/10.1074/jbc.M406314200

49. Volk J, Ziemann C, Leyhausen G, Geurtsen W (2009) Nonirradiated campherquinone induces DNA damage in human gingival fibroblasts. Dent Mater 25:1556-1563. https://doi.org/10.1016/ j.dental.2009.07.009

50. Volk J, Ziemann C, Leyhausen G, Geurtsen W (2018) Genotoxic and mutagenic potential of camphorquinone in L5178/TK(+/-) mouse lymphoma cells. Dent Mater 34:519-530. https://doi.org/ 10.1016/j.dental.2017.12.013

51. Wessels M, Leyhausen G, Volk J, Geurtsen W (2014) Oxidative stress is responsible for genotoxicity of camphorquinone in primary human gingival fibroblasts. Clin Oral Investig 18:1705-1710. https://doi.org/10.1007/s00784-013-1178-x

52. Geurtsen W, Spahl W, Leyhausen G (1998) Residual monomer/ additive release and variability in cytotoxicity of light-curing glass-ionomer cements and compomers. J Dent Res 77:20122019. https://doi.org/10.1177/00220345980770121001

53. Bationo R, Jordana F, Boileau MJ, Colat-Parros J (2016) Release of monomers from orthodontic adhesives. Am J Orthod Dentofac Orthop 150:491-498. https://doi.org/10.1016/j.ajodo.2016.02.027

54. Durner J, Debiak M, Burkle A, Hickel R, Reichl FX (2011) Induction of DNA strand breaks by dental composite components compared to X-ray exposure in human gingival fibroblasts. Arch Toxicol 85:143-148. https://doi.org/10.1007/s00204-010-0558-0

55. Kloukos D, Pandis N, Eliades T (2013) Bisphenol-a and residual monomer leaching from orthodontic adhesive resins and polycarbonate brackets: a systematic review. Am J Orthod Dentofac Orthop 143:S104-12.e1-2. https://doi.org/10.1016/j.ajodo.2012. 11.015

56. Spahl W, Budzikiewicz H, Geurtsen W (1998) Determination of leachable components from four commercial dental composites by gas and liquid chromatography/mass spectrometry. J Dent 26:137145

57. Liebenberg WH (1993) Rubber dam isolation of the working field in orthodontics. J Clin Orthod 27:276-282

Publisher's note Springer Nature remains neutral with regard to jurisdictional claims in published maps and institutional affiliations. 